\title{
5-hydroxytryptamine strongly inhibits fluid secretion in guinea pig pancreatic duct cells
}

\author{
Atsushi Suzuki, Satoru Naruse, Motoji Kitagawa, Hiroshi Ishiguro, Toshiyuki Yoshikawa, \\ Shigeru B.H. Ko, Akiko Yamamoto, Hiroyuki Hamada, and Tetsuo Hayakawa
}

Internal Medicine II, Nagoya University School of Medicine, Nagoya, Japan

Address correspondence to: Satoru Naruse, Internal Medicine II, Nagoya University School of Medicine, 65 Tsurumai-cho, Showa-ku, Nagoya 466-8550, Japan. Phone: 81-52-744-2170; Fax: 81-52-744-2179; E-mail: snaruse@med.nagoya-u.ac.jp.

Received for publication January 22, 2001, and accepted in revised form July 24, 2001.

\begin{abstract}
We studied the distribution of 5-hydroxytryptamine- (5-HT-) containing cells in the guinea pig pancreas and examined the effects of 5-HT on fluid secretion by interlobular pancreatic ducts. The 5-HT-immunoreactive cells with morphological characteristics of enterochromaffin (EC) cells were scattered throughout the duct system and were enriched in islets of Langerhans. The fluid secretory rate in the isolated interlobular ducts was measured by videomicroscopy. Basolateral applications of 5-HT strongly but reversibly reduced $\mathrm{HCO}_{3}$-dependent, as well as secretin- and acetylcholine- (ACh-) stimulated, fluid secretion, whereas 5-HT applied into the lumen had no such effects. Secretin-stimulated fluid secretion could be inhibited by a $5-\mathrm{HT}_{3}$ receptor agonist, but not by agonists of the $5-\mathrm{HT}_{1}, 5-\mathrm{HT}_{2}$, or 5- $\mathrm{HT}_{4}$ receptors. Under the stimulation with secretin, 5-HT decreased the intracellular $\mathrm{pH}\left(\mathrm{pH}_{\mathrm{i}}\right)$ and reduced the rate of $\mathrm{pH}_{\mathrm{i}}$ recovery after acid loading with $\mathrm{NH}_{4}{ }^{+}$, suggesting that 5 -HT inhibits the intracellular accumulation of $\mathrm{HCO}_{3}{ }^{-}$. The elevation of intraductal pressure in vivo reduced secretin-stimulated fluid secretion, an effect that could be attenuated by a $5-\mathrm{HT}_{3}$ receptor antagonist. Thus, 5-HT, acting through basolateral $5-\mathrm{HT}_{3}$ receptors, strongly inhibits spontaneous, secretin-, and ACh-stimulated fluid secretion by guinea pig pancreatic ducts. 5-HT released from pancreatic ductal EC cells on elevation of the intraductal pressure may regulate fluid secretion of neighboring duct cells in a paracrine fashion.
\end{abstract}

J. Clin. Invest. 108:749-756 (2001). DOI:10.1172/JCI200112312.

\section{Introduction}

The gastrointestinal tract is the major source of serotonin, 5-hydroxytryptamine (5-HT); a large amount of 5 -HT is concentrated in the enterochromaffin (EC) cells and the submucosal and myenteric neurons $(1,2)$. Mechanical distension of the intestinal mucosa and a variety of neurohormonal stimuli have been shown to release 5-HT from the EC cells mainly into the interstitial space (3), but also into the gut lumen $(4,5)$. The released 5-HT binds various subtypes of 5-HT receptors on enteric neurons, smooth muscle cells, and epithelial cells and regulates intestinal fluid transport and peristalsis $(2,4,6)$.

In the pancreas, 5 -HT is mainly present in $\beta$ cells of the islet of Langerhans $(7,8)$ and in serotonergic pancreatic nerve fibers $(2,9)$. The presence of the EC cells in the exocrine pancreas has also been noticed but their exact localization and function have not been described (8). In the present investigation we examined the distribution of the EC cells in the guinea pig pancreas by immunohistochemical methods and found that they were present throughout the pancreatic duct system. To understand a regulatory function of the EC cells on the neighboring duct cells, we examined the effect of 5-HT on the isolated pancreatic ducts, where the functions of the pancreatic duct in vivo are well preserved (10).

\section{Methods}

The following study was approved by the Ethical Committee of Nagoya University on Animal Use for Experiment.

Immunobistochemistry. Under anesthesia with pentobarbital, female Hartley guinea pigs (300-350 g) were killed by intracardiac perfusion with Ringer's solution for 1 minute followed by $4 \%$ paraformaldehyde for 10 minutes, as described previously (11). The dissected specimens of the pancreas were further dipped in the fixative overnight. They were cryoprotected in graded concentration of sucrose, embedded in OCT compounds, and then frozen. Sections of $4-\mu \mathrm{m}$ thickness were cut by a cryostat and mounted on albumin-coated glass slides. Endogenous peroxidase activity of the sections was blocked with $0.3 \% \mathrm{H}_{2} \mathrm{O}_{2}$ in methanol for 30 minutes at room temperature. The section was incubated with $10 \%$ normal goat serum for 30 minutes and then with mouse anti-serotonin mAb (clone 5HT-H209, 1:200 dilution) for $1-2$ days at $4^{\circ} \mathrm{C}$. It was then incubated with biotinylated anti-mouse IgG (1:200) at room temperature for 2 hours followed by the avidin-biotin-peroxidase complex for 2 hours. The immunoreaction was visualized by $0.02 \%$ diaminobenzidine tetrahydrochloride in $0.05 \mathrm{M}$ Tris- $\mathrm{HCl}$ containing $0.01 \% \mathrm{H}_{2} \mathrm{O}_{2}$ and was examined with an interference contrast microscope (Olympus AX; Olympus Optical Co., Tokyo, Japan). 

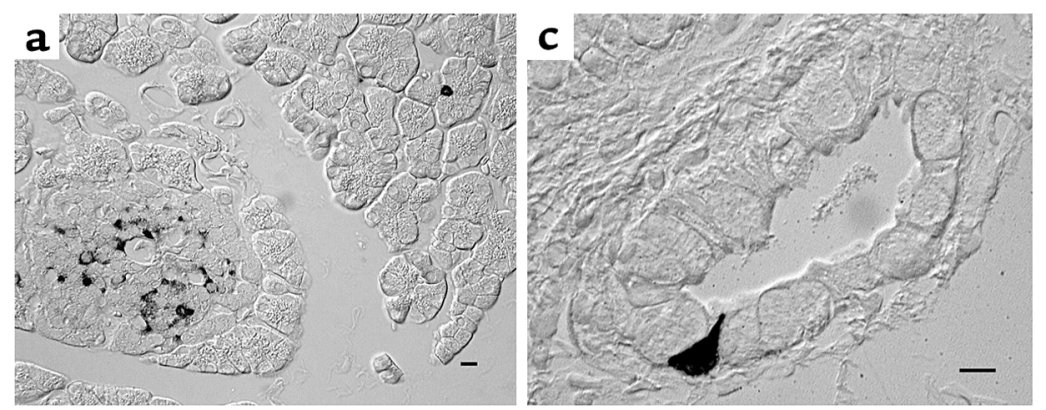

\section{Figure 1}

Immunohistochemistry for 5-HT. The distribution of 5-HT-positive cells in the guinea pig pancreas was examined with mouse anti-serotonin mAb. The majority of 5-HT-immunoreactive cells are present in the islet of Langerhans (a). They are also present in the epithelium of the main (b), larger (c), and smaller (d) interlobular ducts and in acini (a). Bar, $5 \mu \mathrm{m}$.
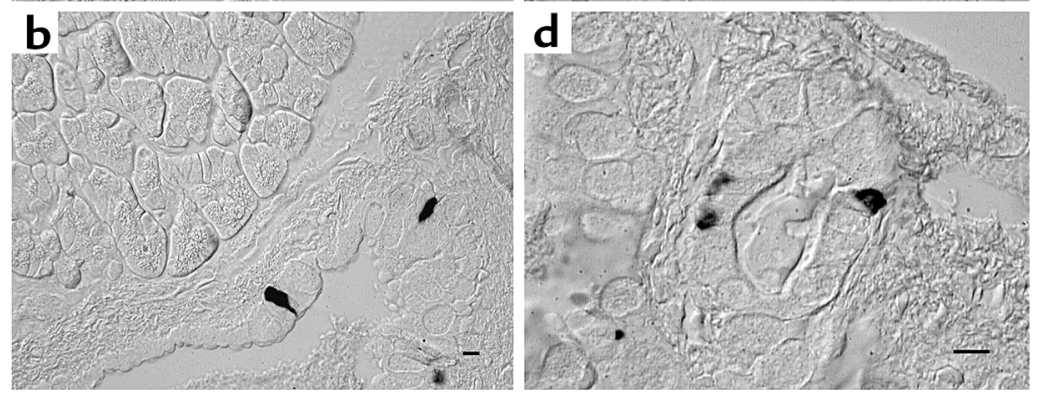

Isolated interlobular ducts. Guinea pigs were killed by cervical dislocation. The pancreas was removed and interlobular ducts were isolated as described previously (12). The duct segments were placed in McCoy's 5A tissue culture medium supplemented with $10 \%$ FCS, $2 \mathrm{mM}$ glutamine, $0.1 \mathrm{mg} / \mathrm{ml}$ soybean trypsin inhibitor, $0.1 \mathrm{IU} / \mathrm{ml}$ insulin and $4 \mu \mathrm{g} / \mathrm{ml}$ dexamethazone. They were cultured at $37^{\circ} \mathrm{C}$ in $5 \% \mathrm{CO}_{2}$ in air for 3 hours, during which time both ends of the interlobular duct segments sealed spontaneously, thus isolating the luminal space from the bathing medium.

Solutions. The standard HEPES-buffered solution contained (in $\mathrm{mM}$ ): $140 \mathrm{NaCl}, 5 \mathrm{KCl}, 1 \mathrm{CaCl}_{2}, 1 \mathrm{MgCl}_{2}$, 10 D-glucose, and 10 HEPES, and was equilibrated with $100 \% \mathrm{O}_{2}$. The standard $\mathrm{HCO}_{3}{ }^{-}$-buffered solution contained (in $\mathrm{mM}$ ): $115 \mathrm{NaCl}, 5 \mathrm{KCl}, 1 \mathrm{CaCl}_{2}, 1 \mathrm{MgCl}_{2}, 10$ D-glucose, and $25 \mathrm{NaHCO}_{3}$, and was equilibrated with $95 \% \mathrm{O}_{2}-5 \% \mathrm{CO}_{2}$. In the solution containing $\mathrm{NH}_{4} \mathrm{Cl}(20$ $\mathrm{mM}), \mathrm{NaCl}$ was reduced to $95 \mathrm{mM}$. The solutions were adjusted to $\mathrm{pH} 7.4$ at $37^{\circ} \mathrm{C}$.

Measurement of the fluid secretory rate in isolated ducts. The cultured ducts were stored at $4^{\circ} \mathrm{C}$ in the standard HEPES-buffered solution before use. The fluid secretory rate into the closed luminal space was measured by a modification of the methods described previously $(10,13)$. The ducts were attached to the glass coverslips pretreated with Cell-Tak (Becton Dickinson Labware, Bedford, Massachusetts, USA) and were superfused at $37^{\circ} \mathrm{C}$ on the stage of an inverted Olympus IX microscope (Olympus Optical Co.). The brightfield images of the duct were obtained at 1-minute intervals using a charge coupled device (CCD) camera. To determine the fluid secretory rate, the initial values for the length $\left(L_{0}\right)$, diameter $\left(2 R_{0}\right)$ and image area $\left(A_{0}\right)$ of the duct lumen were measured in the first image of the series. The initial volume $\left(V_{0}\right)$ of the duct lumen was calculated, assuming cylindrical geometry, as $\pi R_{0}^{2} L_{0}$. The values of $L_{0}, R_{0}$, and $V_{0}$ of the ducts used for experiments were $270 \pm 10 \mu \mathrm{m}, 60 \pm 4 \mu \mathrm{m}$, and $3.2 \pm 0.4 \mathrm{nl}$ (mean \pm SEM, $n=48$ ), respectively. The luminal surface area of the epithelium was taken to be $2 \pi R_{0} L_{0}$. In subsequent images of the series, the luminal image area $(A)$ was expressed as the relative area $\left(A / A_{0}\right)$. The relative volume $\left(V / V_{0}\right)$ was estimated from the relative area assuming $V / V_{0}=\left(A / A_{0}\right)^{3 / 2}$. The rate of fluid secretion was calculated at 1 -minute intervals from the increment in duct volume and expressed as the secretory rate per unit luminal area of epithelium (nanoliters per minute per square millimeter.)

Micropuncture of the lumen. To investigate the effects of luminal 5-HT, the lumen of the cultured ducts was micropunctured with a double-barreled micropipette as described previously (10). The luminal fluid was withdrawn and replaced by the standard HEPESbuffered solution with or without 5-HT $(1 \mu \mathrm{M})$.

Measurement of $\left[\mathrm{Ca}^{2+}\right]_{i}$. Intracellular free $\mathrm{Ca}^{2+}$ concentration $\left(\left[\mathrm{Ca}^{2+}\right]_{\mathrm{i}}\right)$ was estimated by microfluorometry in duct cells loaded with fura-2 as described previously (14). The cultured duct segments were incubated for 90 minutes at room temperature with the acetoxymethyl ester fura-2/AM $(3 \mu \mathrm{M})$. Microfluorometry was performed on a small area of the ductal epithelium (10-20 cells).

Measurement of intracellular $p H\left(p H_{i}\right)$. Intracellular $\mathrm{pH}$ $\left(\mathrm{pH}_{\mathrm{i}}\right)$ was estimated by microfluorometry in duct cells loaded with 2'7'-bis(2-carboxyethyl)-5(6)-carboxyfluorescein (BCECF) as described previously (12). The cultured duct segments were incubated for 10 minutes at room temperature with the acetoxymethyl ester BCECF-AM $(2 \mu \mathrm{M})$. Microfluorometry was performed on the ductal epithelium illuminated alternately at $430 \mathrm{~nm}$ and $480 \mathrm{~nm}$. Values of $\mathrm{pH}_{\mathrm{i}}$ were calculated from the fluorescence ratio $\left(F_{480} / F_{430}\right)$ measured at 530 $\mathrm{nm}$. In situ calibration was performed using the high$\mathrm{K}^{+}$/nigericin technique. 


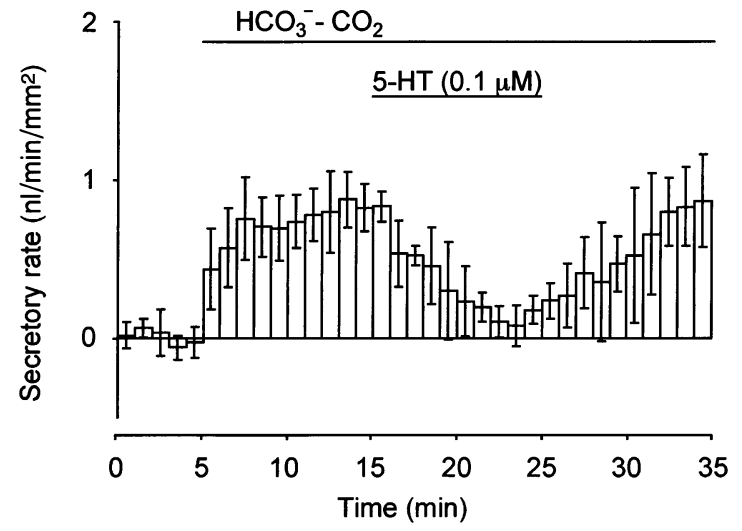

Figure 2

Effects of 5-HT on basal fluid secretion in interlobular duct segments isolated from guinea pig pancreas. The closed ducts were initially superfused with $\mathrm{HCO}_{3}{ }^{-}-\mathrm{CO}_{2}$-free HEPES-buffered solution. After a 5-minute period, the bath solution was switched to the standard $\mathrm{HCO}_{3}{ }^{-}-\mathrm{CO}_{2}$-buffered solution. After a further 10 minutes, $0.1 \mu \mathrm{M}$ $5-\mathrm{HT}$ was added to the bath in the presence of $\mathrm{HCO}_{3}{ }^{-}-\mathrm{CO}_{2}$. The fluid secretory rates are shown as means \pm SEM of four experiments.

Pancreatic fluid secretion in anesthetized guinea pigs. Guinea pigs were anesthetized by an intraperitoneal injection of pentobarbital. The trachea was cannulated for artificial ventilation. Saline was infused intravenously at $5 \mathrm{ml} /$ hour via a polyethylene tube placed in the external jugular vein throughout the experiments. The abdomen was opened through a midline incision, and the main pancreatic duct was cannulated with a polyethylene tube. The cannula was connected with a silastic tube ( $1 \mathrm{~mm}$, inner diameter) to a $26 \mathrm{G}$ needle attached to a manipulator placed over an electric balance. Pancreatic juice was allowed to drop from the needle so that fluid secretion was measured continuously by a gravimeter using a computer-controlled electric balance (14). The outlet of the needle was positioned at the level of the pancreas $\left(0 \mathrm{cmH}_{2} \mathrm{O}\right)$ using a manipulator. Secretin $(1 \mu \mathrm{g} / \mathrm{kg} / \mathrm{h})$ and granisetron $(40$ $\mu \mathrm{g} / \mathrm{kg} / \mathrm{h}$ ) were infused intravenously with saline. Hydrostatic pressure of $3.0 \mathrm{cmH}_{2} \mathrm{O}$ above the initial level was applied to the duct system for 5 minutes by raising the position of the needle.

Materials. Antiserotonin mAb (clone 5HT-H209) was obtained from Biomeda Corp. (Foster City, California, USA); biotinylated anti-mouse IgG from Amersham International (Little Chalfont, United Kingdom); avidin-biotin-peroxidase complex from Vector Laboratories (Burlingame, California, USA); secretin from the Peptide Institute (Minoh-shi, Osaka, Japan); acetylcholine (ACh), 5-HT, and 5-carboxyamidotryptamine (5-CT) from Sigma Chemical Co. (St. Louis, Missouri, USA); 2-methyl-5-hydroxytryptamine (2-methyl-5HT), 5-methoxytryptamine (5-MeOT), and $\alpha$-methyl5 -hydroxytryptamine ( $\alpha$-methyl-5-HT) from Research Biochemical International (Natick, Massachusetts, USA); granisetron from Nippon Roche k.k (Tokyo, Japan); fura-2/AM from Dojindo Laboratories
(Kumamoto, Japan); and BCECF-AM from Molecular Probes Inc. (Eugene, Oregon, USA).

Statistics. Data are presented as means \pm SEM. Statistical analysis was carried out by ANOVA followed by Student's $t$ test for paired or unpaired data. $P$ values less than 0.05 was considered significant.

\section{Results}

5-HT-containing cells in the pancreas. Numerous 5HT-immunoreactive cells were found in the islet of Langerhans (Figure 1a), and 5-HT-immunoreactive cells were scattered in the epithelium of the main duct (Figure 1b), interlobular ducts (diameter 25-500 $\mu \mathrm{m}$ ) (Figure 1, $\mathrm{c}$ and $\mathrm{d}$ ), intralobular ducts, and in acini (Figure 1a). They were pyramid shaped and had a slender process toward the lumen.

Effects of 5-HTon spontaneous $\left(\mathrm{HCO}_{3}^{-}\right.$-dependent) fluid secretion. There was little ductal fluid secretion $(0.01 \pm 0.13$ $\left.\mathrm{nl} / \mathrm{min} / \mathrm{mm}^{2} ; n=4\right)$ during superfusion with $\mathrm{HCO}_{3}{ }^{-}$$\mathrm{CO}_{2}$-free HEPES-buffered solution (Figure 2). The fluid secretory rate increased to $0.78 \pm 0.02 \mathrm{nl} / \mathrm{min} / \mathrm{mm}^{2}$ when the bath solution was switched to the standard $\mathrm{HCO}_{3}-$
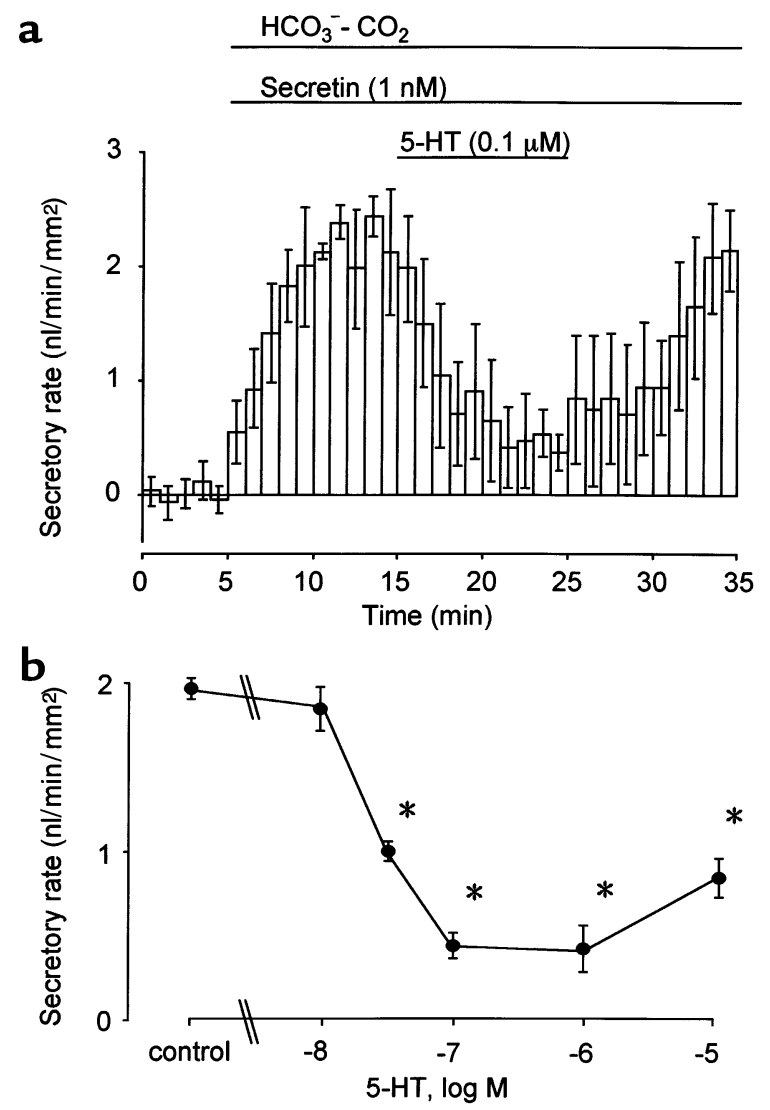

Figure 3

Effects of 5-HT on secretin-stimulated fluid secretion. (a) Ducts were stimulated with $1 \mathrm{nM}$ secretin in the presence of $\mathrm{HCO}_{3}{ }^{-}-\mathrm{CO}_{2} .5-\mathrm{HT}$ $(0.1 \mu \mathrm{M})$ was added to the bath during stimulation with $1 \mathrm{nM}$ secretin. (b) Concentration-response curve for the effects of 5-HT on secretin-stimulated fluid secretion. The fluid secretory rates are shown as means \pm SEM of four experiments. Asterisks indicate significant $(P<0.01)$ differences. 


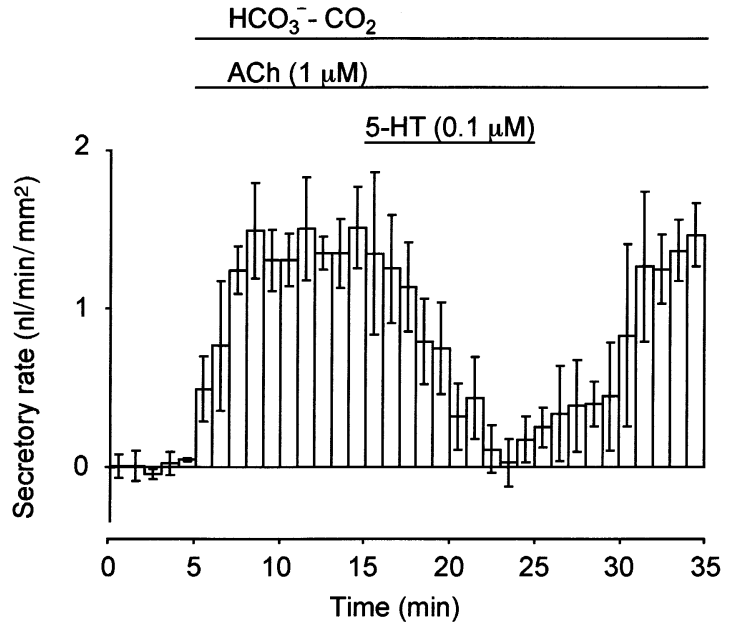

Figure 4

Effects of 5-HT on ACh-stimulated fluid secretion. Ducts were stimulated with $1 \mu \mathrm{M} \mathrm{ACh}$ in the presence of $\mathrm{HCO}_{3}{ }^{-}-\mathrm{CO}_{2} .5-\mathrm{HT}(0.1 \mu \mathrm{M})$ was added to the bath during stimulation with $1 \mu \mathrm{M} \mathrm{ACh}$. The fluid secretory rates are shown as means \pm SEM of four experiments.

$\mathrm{CO}_{2}$-buffered solution. The application of 5-HT $(0.1 \mu \mathrm{M})$ reduced spontaneous $\left(\mathrm{HCO}_{3}\right.$-dependent) fluid secretion significantly $(P<0.01)$ to $0.22 \pm 0.04 \mathrm{nl} / \mathrm{min} / \mathrm{mm}^{2}$ in 7 minutes. When the application of 5-HT was halted, fluid secretion recovered in 10 minutes.

Effects of 5-HT on secretin-stimulated fluid secretion. Secretin $(1 \mathrm{nM})$ increased the fluid secretory rate to $2.23 \pm 0.05 \mathrm{nl} / \mathrm{min} / \mathrm{mm}^{2}(n=24)$, which remained constant over 15 minutes. When 5 -HT at concentrations of $0.01,0.03,0.1$ (Figure $3 \mathrm{a}$ ), 1 , or $10 \mu \mathrm{M}$ was added to the bath, 5-HT $(>0.03 \mu \mathrm{M})$ significantly $(P<0.01)$ inhibited the secretin-stimulated fluid secretion. The inhibitory effect was concentration dependent at a range of 0.01 to $0.1 \mu \mathrm{M}$, and $\mathrm{IC}_{50}$ was approximately $0.03 \mu \mathrm{M}$ (Figure $3 \mathrm{~b}$ ).

Effects of 5-HT on ACh-stimulated fluid secretion. ACh $(1 \mu \mathrm{M})$ increased the fluid secretory rate to $1.42 \pm 0.04$ $\mathrm{nl} / \mathrm{min} / \mathrm{mm}^{2}$, which remained constant for over 20 minutes $(n=4)$. The application of $0.1 \mu \mathrm{M} 5$-HT to the bath reversibly reduced ACh-stimulated fluid secretion by $73.4 \% \pm 0.7 \%(P<0.01$, Figure 4$)$.

Effects of 5-HT receptor agonists on secretin-stimulated fluid secretion. To identify the subtypes of 5-HT receptors that are responsible for the inhibition of fluid secretion, the effects of 5-HT receptor agonists on secretin-stimulated $(1 \mathrm{nM})$ fluid secretion were examined. The application of $1 \mu \mathrm{M} 2$-methyl-5-HT (5- $\mathrm{HT}_{3}$ receptor agonist) significantly $(P<0.01)$ reduced fluid secretion by $82.4 \% \pm 4.1 \%$ $\left(n=4\right.$; Figure 5a). However, 5-CT $\left(5-\mathrm{HT}_{1}\right.$ receptor agonist), $\alpha$-methyl-5-HT (5- $\mathrm{HT}_{2}$ receptor agonist), and $5-\mathrm{MeOT}\left(5-\mathrm{HT}_{4}\right.$ receptor agonist) failed to inhibit secretin-stimulated fluid secretion (Figure 5b).

Effects of luminal 5-HT on secretin-stimulated fluid secretion. To examine the effects of luminal 5-HT on fluid secretion, the ducts were filled with the standard $\mathrm{HCO}_{3}{ }^{-}$$\mathrm{CO}_{2}$-free HEPES-buffered solution with or without 1 $\mu \mathrm{M}$ of 5-HT. In the presence of 5-HT in the lumen, the introduction of $\mathrm{HCO}_{3}{ }^{-}-\mathrm{CO}_{2}$ to the bath evoked fluid secretion of $2.22 \pm 0.14 \mathrm{nl} / \mathrm{min} / \mathrm{mm}^{2}(n=4$; Figure $6 \mathrm{a})$, which was not significantly different from that without 5-HT (Figure 6b). Secretin-stimulated fluid secretion $\left(3.04 \pm 0.10 \mathrm{nl} / \mathrm{min} / \mathrm{mm}^{2}\right)$ was also unaffected by the luminal application of 5-HT (Figure 6b).

The effect of 5-HT on $\left[\mathrm{Ca}^{2+}\right]_{i}$ in duct cells. ACh $(1 \mu \mathrm{M})$ induced a sustained increase in $\left[\mathrm{Ca}^{2+}\right]_{\mathrm{i}}$, while $5-\mathrm{HT}$ $(1 \mu \mathrm{M})$ caused a smaller transient increase in $\left[\mathrm{Ca}^{2+}\right]_{\mathrm{i}}$ as compared with ACh (data not shown). When 5-HT $(1 \mu \mathrm{M})$ was applied during the stimulation with ACh $(1 \mu \mathrm{M}),\left[\mathrm{Ca}^{2+}\right]_{\mathrm{i}}$ showed a transient increase over the plateau response to $\mathrm{ACh}$.

The effect of 5-HT on $p H_{i}$ in duct cells. When 5-HT $(1 \mu \mathrm{M})$ was applied to the bath during the stimulation with secretin $\left(1 \mathrm{nM}\right.$ ), $\mathrm{pH}_{\mathrm{i}}$ started to decrease gradually (Figure $7 \mathrm{a})$. The initial rate of acidification was $0.024 \pm 0.004 \mathrm{pH}$
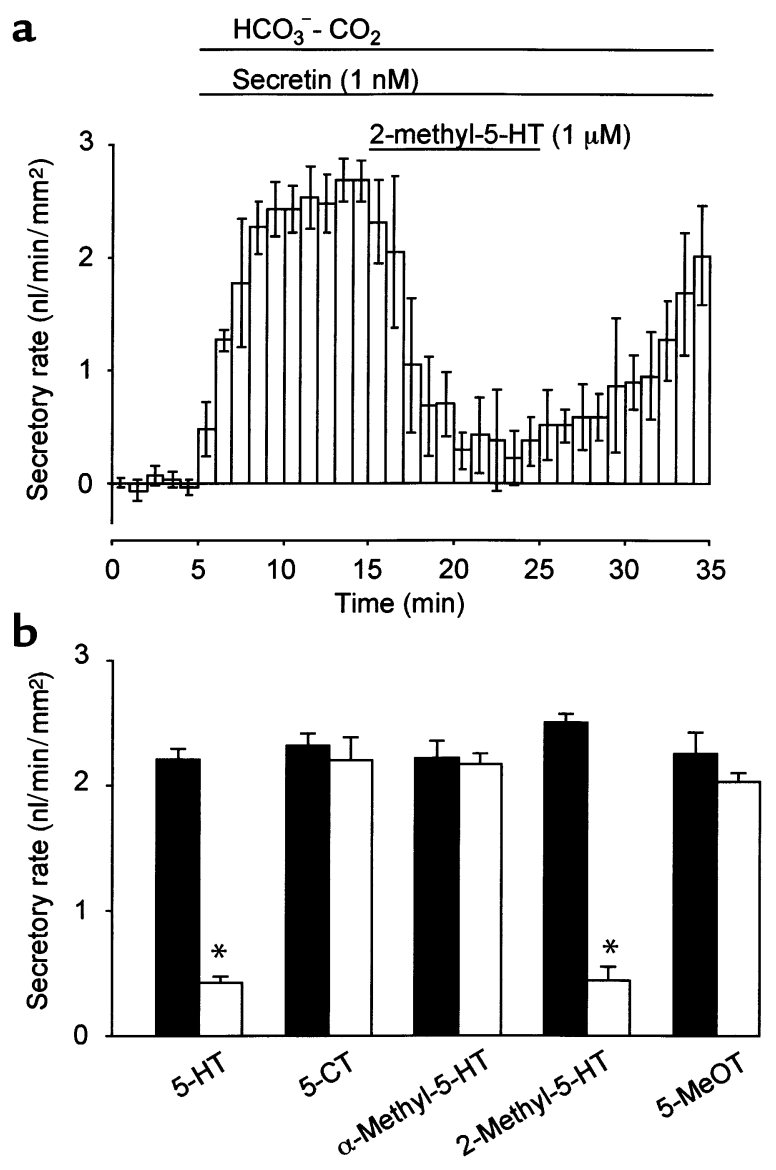

Figure 5

Effects of 5-HT receptor agonists on secretin-stimulated fluid secretion. (a) One micrommolar of 2-methyl-5- $\mathrm{HT}$ (5- $\mathrm{HT}_{3}$ receptor agonist) was added to the bath during stimulation with $1 \mathrm{nM}$ secretin. (b) Effects of $1 \mu \mathrm{M}$ of 5-HT, 5-CT (5- $\mathrm{HT}_{1}$ receptor agonist), $\alpha$-methyl-5$\mathrm{HT}$ (5- $\mathrm{HT}_{2}$ receptor agonist), 2-methyl-5- $\mathrm{HT}$ (5- $\mathrm{HT}_{3}$ receptor agonist), and $5-\mathrm{MeOT}$ (5- $\mathrm{HT}_{4}$ receptor agonist) on secretin-stimulated fluid secretion. Filled bars, the secretory rate before the application of 5-HT agonists. Open bars, the secretory rate in the presence of 5-HT agonists. The fluid secretory rates are shown as mean \pm SEM of four experiments. Asterisks indicate significant $(P<0.01)$ differences. 
$\mathbf{a}$

a
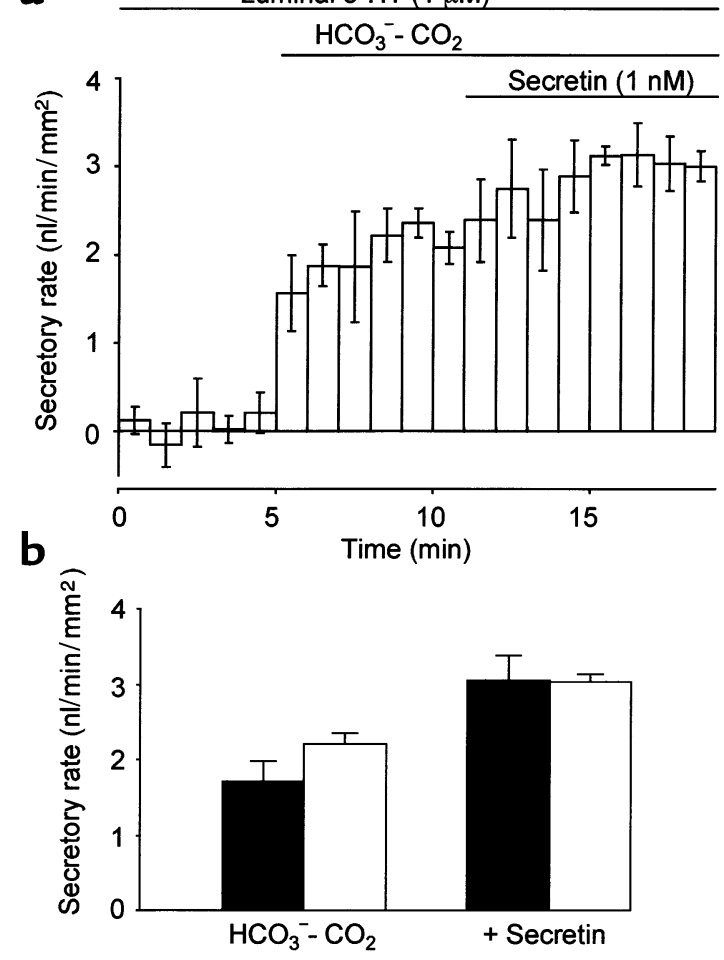

Figure 6

Effects of luminal 5-HT on fluid secretion. The lumen of the cultured ducts was micropunctured and the luminal fluid was replaced by the HEPES-buffered solution with or without 5-HT $(1 \mu \mathrm{M})$. The ducts were initially superfused with HEPES-buffered solution for 5 minutes. The bath solution was switched to the $\mathrm{HCO}_{3}{ }^{-}-\mathrm{CO}_{2}-$ buffered solution. After a 6 -minute period, $1 \mathrm{nM}$ secretin was added to the bath. (a) The fluid secretory rate in ducts injected with 5 - $\mathrm{HT}(1 \mu \mathrm{M})$. Mean \pm SEM of four experiments. (b) Spontaneous $\left(\mathrm{HCO}_{3}{ }^{-}-\mathrm{CO}_{2}\right.$-dependent) and secretin-stimulated $(1 \mathrm{nM})$ fluid secretion in the absence (filled bars) and presence (open bars) of luminal $5-\mathrm{HT}(1 \mu \mathrm{M})$. Mean \pm SEM of four experiments.

unit per minute $(n=6)$. When duct cells were acid loaded with the $\mathrm{NH}_{4}{ }^{+}$pulse technique, the initial rate of the $\mathrm{pH}_{\mathrm{i}}$ recovery $(0.099 \pm 0.030 \mathrm{pH}$ unit per minute) was significantly $(P<0.01)$ reduced to $0.033 \pm 0.024 \mathrm{pH}$ unit per minute in the presence of 5-HT $(1 \mu \mathrm{M})(n=5$; Figure $7 \mathrm{~b})$.

Effects of intraductal pressure on secretin-stimulated fluid secretion in vivo. An intravenous infusion of secretin $(1 \mu \mathrm{g} / \mathrm{kg} / \mathrm{h})$ induced steady pancreatic fluid secretion $(22.5 \pm 1.8 \mu \mathrm{l} / \mathrm{min} / \mathrm{g}$ wet weight of pancreas; $n=4$ ) for over 1 hour (Figure 8 ). When a hydrostatic pressure of $+3.0 \mathrm{cmH}_{2} \mathrm{O}$ was applied to the pancreatic duct system for a 5 -minute period, the secretory rate dropped significantly $(P<0.01)$ by $5.9 \pm 0.9 \mu \mathrm{l} / \mathrm{min} / \mathrm{g}$. The secretory rate quickly returned to the initial levels when the intraductal pressure was reduced to the initial zero level. An intravenous administration of granisetron $(40 \mu \mathrm{g}$ $\mathrm{kg} / \mathrm{h}$ ), an antagonist of $5-\mathrm{HT}_{3}$ receptor, increased the secretory rate by $4.1 \pm 1.4 \mu \mathrm{l} / \mathrm{min} / \mathrm{g}(P<0.05)$. In the presence of granisetron, the reduction of the secretory rate $(2.8 \pm 1.4 \mu \mathrm{l} / \mathrm{min} / \mathrm{g})$ by the elevation of intraductal pressure $\left(+3.0 \mathrm{cmH}_{2} \mathrm{O}\right)$ was significantly $(P<0.05)$ smaller than that of control (without a $5-\mathrm{HT}_{3}$ receptor antagonist).

\section{Discussion}

5-HT-containing cells in the guinea pig pancreas. The present study confirmed earlier studies that many 5-HT-immunoreactive cells are present in the islet of Langerhans in guinea pigs (8). Insulin and 5-HT are costored within the secretory granules in $\beta$ cells (7); 5-HT that is coreleased with insulin (15) may regulate pancreatic ductal functions. However, it is not known whether a sufficient amount of 5-HT reaches pancreatic duct cells via the efferent vessels from the islet capillary network that communicate the ductal capillary plexus (16).

Previous studies in vivo suggest that serotonergic enteropancreatic nerves inhibit pancreatic fluid and protein secretion via presynaptic receptors on cholinergic nerves $(17,18)$. More recently, Li et al. (19) reported that 5-HT released from the intestinal EC cells activated neuronal $5-\mathrm{HT}_{3}$ and $5-\mathrm{HT}_{4}$ receptors on vagal afferent fibers to mediate luminal factor-stimulated pancreatic secretion in rats. This evidence indicates that 5 -HT regulates pancreatic secretion indirectly by controlling cholinergic nerves.

$\mathbf{a}$
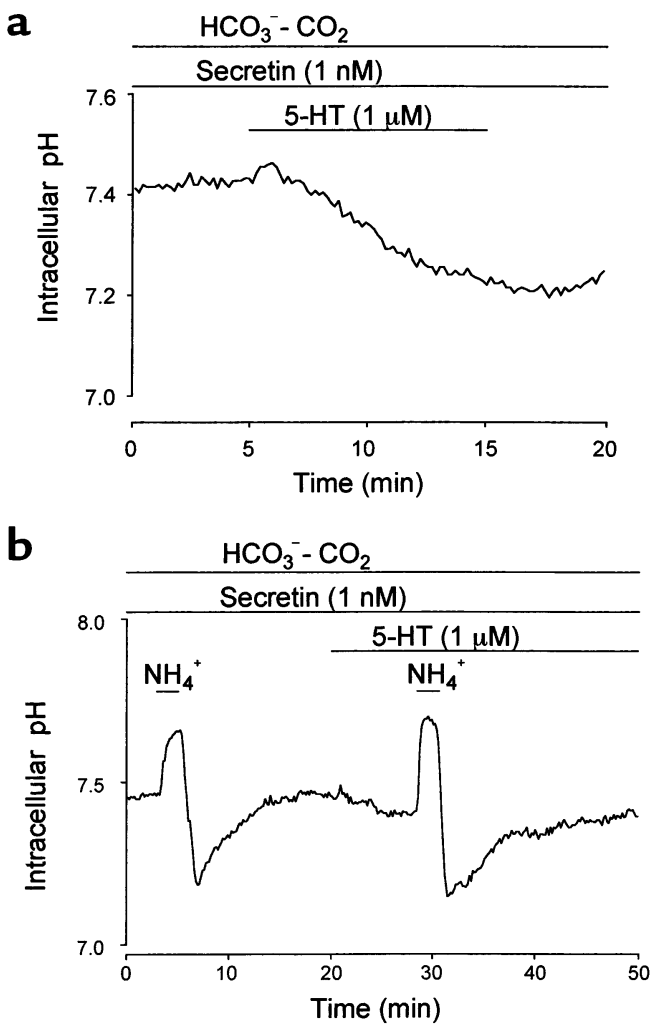

Figure 7

Effect of 5-HT on intracellular $\mathrm{pH}$. Ducts were superfused with the standard $\mathrm{HCO}_{3}^{-}$-buffered solution in the presence of secretin (1 nM). (a) One micrometer 5-HT was applied to the bath. Representative of six experiments. (b) Duct cells were acid loaded by exposure to 2minute pulses of $20 \mathrm{mM} \mathrm{NH}_{4}{ }^{+}$in the absence and presence of 5-HT $(1 \mu \mathrm{M})$. Representative of five experiments. 


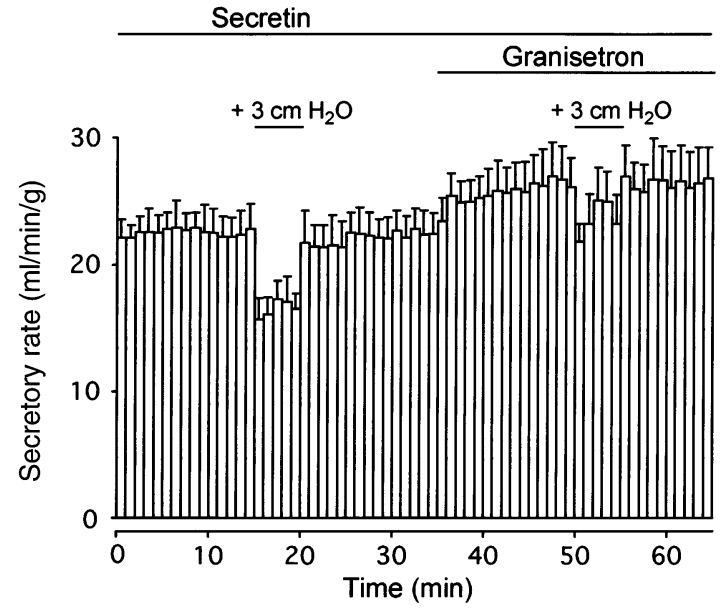

Figure 8

Effects of intraductal pressure on secretin-stimulated fluid secretion in anesthetized guinea pigs. Pancreatic fluid secretion was stimulated with an intravenous infusion of secretin $(1 \mu \mathrm{g} / \mathrm{kg} / \mathrm{h})$. A hydrostatic pressure of $+3.0 \mathrm{~cm} \mathrm{H}_{2} \mathrm{O}$ was applied to the duct system by elevating the position of the outlet of the needle connected to the pancreatic duct without or with an intravenous infusion of granisetron (40 $\mu \mathrm{g} / \mathrm{kg} / \mathrm{h}$ ), a $5-\mathrm{HT}_{3}$ receptor antagonist. Mean $\pm \mathrm{SEM}$ of four experiments in four guinea pigs.

The present study clearly showed that 5-HT-immunoreactive cells with morphological characteristics of EC cells were present throughout the duct system, i.e., the main, intra-, and interlobular ducts. The EC cells in the exocrine pancreas, in contrast to 5-HT-immunoreactive cells in the islets, are unreactive for the pancreatic hormones (8). Since intra- and interlobular ducts are thought to be responsible for most of $\mathrm{HCO}_{3}{ }^{-}$and water secretion in the pancreas (20), this finding leads us to a hypothesis that 5-HT may regulate pancreatic duct cell function locally in a paracrine fashion.

Direct inbibition of ductal fluid secretion by 5-HT. In the isolated interlobular duct segments 5-HT strongly but reversibly inhibited secretin- and ACh-stimulated fluid secretion as well as spontaneous $\left(\mathrm{HCO}_{3}{ }^{-}\right.$-dependent) secretion (Figures 2-4). Because the subepithelial tissues were carefully removed in our preparations, this finding strongly suggests that 5 -HT exerted the inhibitory effect by directly acting on pancreatic duct cells.

The concentration of 5-HT required for a half-maximal inhibition was approximately $30 \mathrm{nM}$ (Figure $3 \mathrm{~b}$ ), which is 10 to 100 times lower compared with those reported in other systems. In isolated rat pancreatic lobules, the maximal inhibition of veratridine-stimulated amylase secretion was obtained by $5-\mathrm{HT}$ at $5-10$ $\mu \mathrm{M}$ (17). In the guinea pig distal colon, 5-HT at 0.1-1 $\mu \mathrm{M}$ stimulated $\mathrm{Cl}^{-}$transport via cholinergic nerves $(21,22)$. Direct stimulation of epithelial $\mathrm{Cl}^{-}$transport by 5 -HT was observed at $0.05-1 \mu \mathrm{M}$ in rat choroid plexus (23), at $1-100 \mu \mathrm{M}$ in rat trachea (24), and at $0.1-1 \mu \mathrm{M}$ in rat epididymis (25).

Neurohormonal agents that have been shown to inhibit pancreatic ductal secretion directly are sub- stance $\mathrm{P}$, arginine vasopressin, and ATP. Substance $\mathrm{P}$ (0.1-10 nM) inhibited secretin-stimulated fluid secretion by $60-80 \%$ in isolated rat pancreatic ducts (26). In guinea pig ducts, secretin-stimulated fluid secretion was inhibited with vasopressin (100 nM) by 30\% (14) and with $\operatorname{ATP}(1 \mu \mathrm{M})$ by $40 \%$ (27). In the present study, 5 -HT, irrespective of stimuli, reduced ductal fluid secretion by about $75 \%$. Thus, 5 -HT is a new candidate agent that directly regulates pancreatic ductal fluid secretion.

$5-\mathrm{HT}_{3}$ receptor on duct cell mediates the inhibition. Several subtypes of 5-HT receptors have been identified in the gastrointestinal tract (6). The $5-\mathrm{HT}_{1 \mathrm{~A}}$ receptor is present in the enteric nerves and ganglia and inhibits the release of ACh. 5- $\mathrm{HT}_{1 \mathrm{p}}$ receptor is a major neuronal receptor that mediates neurotransmission in submucosal and myenteric plexuses. The $5-\mathrm{HT}_{2 \mathrm{~A}}$ and $5-\mathrm{HT}_{2 \mathrm{~B}}$ receptors are present on vascular and intestinal smooth muscle and epithelial cells and are coupled to phosphoinositol metabolism. The 5- $\mathrm{HT}_{3}$ receptor is a ligand-gated nonspecific cation channel $(28,29)$ and is present on submucosal and myenteric neurons. The $5-\mathrm{HT}_{4}$ receptor is present on neurons, smooth muscle cells, and epithelial cells and is coupled to adenylate cyclase.

In guinea pig pancreatic ducts, secretin-stimulated fluid secretion was inhibited by the specific agonist of $5-\mathrm{HT}_{3}$ receptor but not by $5-\mathrm{HT}_{1}, 5-\mathrm{HT}_{2}$, and $5-\mathrm{HT}_{4}$ receptors' agonists (Figure $5 \mathrm{~b}$ ), suggesting that $5-\mathrm{HT}_{3}$ receptor mediates the inhibition. Although $5-\mathrm{HT}_{3}$ receptor is believed to be exclusively located on neurons (30), some previous studies showed weak binding of zacopride, a high-affinity ligand for detecting $5-\mathrm{HT}_{3}$ binding sites at the luminal side of the intestinal mucosa $(31,32)$. A recent immunolabeling study also indicated that $5-\mathrm{HT}_{3}$ receptor was present on both enterocytes and nerve processes (33).

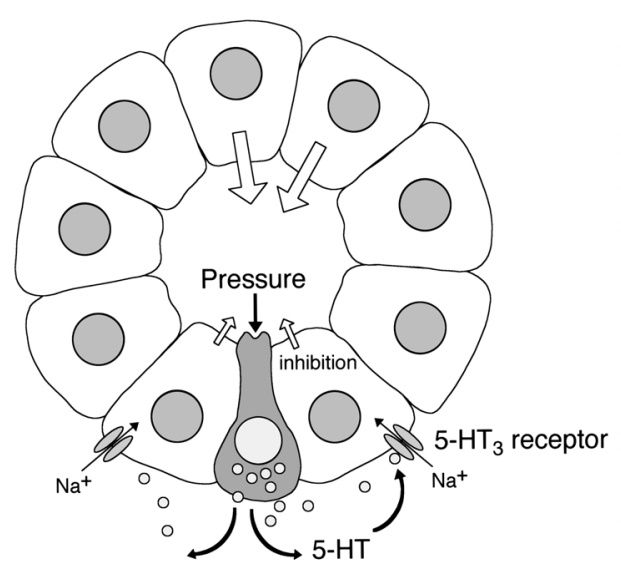

\section{Figure 9}

A hypothetical function of 5-HT: a local feedback control of pancreatic duct fluid secretion by the luminal pressure. EC cell-like cells in the duct epithelium are pressure-responsive sensory receptors. The increase in the luminal pressure stimulates the release of 5-HT into interstitium. 5-HT binds to its receptors on the basolateral membrane of the duct cells and inhibits fluid secretion. 
Luminal 5-HT does not inbibit fluid secretion. In a previous study, we demonstrated that spontaneous ductal fluid secretion was largely dependent on the presence of $\mathrm{Cl}^{-}$within the lumen (10). Since the solution injected into the lumen contains high concentration of $\mathrm{Cl}^{-}$ (149 $\mathrm{mM})$, the rate of spontaneous fluid secretion was higher than that in nonpunctured ducts, where the luminal fluid probably contained higher concentration of $\mathrm{HCO}_{3}{ }^{-}$and lower concentration of $\mathrm{Cl}^{-}$.

In the gastrointestinal EC cells, most of 5-HT is secreted from the basolateral membrane by exocytosis (3), but it is also released into the lumen $(4,5)$. When 5-HT was applied to the intestinal mucosa, it evoked $\mathrm{Cl}^{-}$secretion (5). In the present study, previous administration of 5-HT into the lumen failed to affect basal and secretin-stimulated fluid secretion, suggesting that only the basolateral, but not luminal, 5-HT receptor mediates the inhibition of fluid secretion.

Cellular mechanisms for 5-HT-induced inbibition. In pancreatic duct cells, secretin and ACh stimulates $\mathrm{HCO}_{3}^{-}$ and fluid secretion by elevating intracellular cAMP and $\mathrm{Ca}^{2+}$, respectively (20). We have shown previously that in secretin-stimulated ducts isolated from guinea pig pancreas $\mathrm{HCO}_{3}{ }^{-}$is actively accumulated in the cell, mainly by $\mathrm{Na}^{+}-\mathrm{HCO}_{3}{ }^{-}$cotransport (12). $\mathrm{HCO}_{3}{ }^{-}$is transported into the lumen via a cAMP-sensitive pathway (34). ACh also stimulated $\mathrm{HCO}_{3}{ }^{-}$secretion in this preparation (34), but the transport mechanisms have not been fully investigated. Because 5-HT inhibited both secretin- and ACh-stimulated fluid secretion in this study, it is unlikely that 5-HT exerts the inhibitory effect via its action on receptors of the secretagogues or their intracellular messengers.

The $5-\mathrm{HT}_{3}$ receptor that mediates the ductal fluid inhibition is a member of the ligand-gated ion channel family $(28,29)$. Although a transient increase of $\left[\mathrm{Ca}^{2+}\right]_{\mathrm{i}}$ by 5 -HT per se may not be directly related to the inhibition of fluid secretion, it is probably caused by the opening of serotonin-gated nonselective cation channels on pancreatic duct cells (35). Activation of this channel by $5-\mathrm{HT}$ would also cause $\mathrm{Na}^{+}$influx into the cell. This would reduce the inward gradient of $\mathrm{Na}^{+}$, which is necessary for the accumulation of $\mathrm{HCO}_{3}{ }^{-}$via the basolateral $\mathrm{Na}^{+}-\mathrm{HCO}_{3}{ }^{-}$cotransport. Indeed, the application of 5-HT decreased $\mathrm{pH}_{\mathrm{i}}$ and reduced the rate of $\mathrm{pH}_{\mathrm{i}}$ recovery from acid loading during stimulation with secretin. Moreover, the initial rate of acidification by 5 -HT $(0.024 \mathrm{pH}$ unit per minute) was comparable to that observed in the presence of $\mathrm{H}_{2} \mathrm{DIDS}(0.027 \mathrm{pH}$ unit per minute), a potent blocker of $\mathrm{Na}^{+}-\mathrm{HCO}_{3}{ }^{-}$cotransport (12). These results support a view that 5-HT inhibits fluid and $\mathrm{HCO}_{3}$ secretion by abolishing the activity of $\mathrm{Na}^{+}-\mathrm{HCO}_{3}^{-}$ cotransport almost completely.

A bypothetical function of ductal EC cells. Our present findings suggest that 5-HT released from the EC cells in the ductal epithelium may directly regulate fluid secretion from neighboring duct cells in a paracrine fashion (Figure 9). Bülbring (4) originally proposed that the EC cells in the gut are pressure-responsive sensory receptors that secrete 5-HT and regulate intestinal peristalsis and secretion. Similarly, the EC cells in the pancreatic duct may function as intraductal pressure sensors and regulate ductal fluid secretion. When the intraluminal pressure of pancreatic ducts increases, 5-HT is released into the interstitium from the ductal EC cells, and the released 5 -HT binds to $5-\mathrm{HT}_{3}$ receptors on the basolateral membrane of duct cells and inhibits fluid secretion.

To test this hypothesis, we examined the effect of the intraductal pressure on secretin-stimulated fluid secretion in vivo. In isolated segments of guinea pig ileum, peristalsis was induced when the intraluminal pressure was elevated to $0.3-2.0 \mathrm{cmH}_{2} \mathrm{O}(36)$, which may be mediated by the release of 5-HT (2). In the present study, the elevation of the intraductal pressure by $+3.0 \mathrm{cmH}_{2} \mathrm{O}$ induced a reversible reduction of fluid secretion by $26 \%$, which was significantly attenuated (51\%) by a $5-\mathrm{HT}_{3}$ receptor antagonist (Figure 8 ). This observation is consistent with a hypothesis deduced from our observations in vitro that ductal fluid secretion is controlled by 5 -HT released on elevation of the intraductal pressure. This local feedback mechanism would be beneficial for preventing damage to the exocrine system when the luminal pressure was elevated by the ductal stricture or protein plug that disturbs the flow of pancreatic juice.

In summary, we have shown that 5-HT-containing cells are present in the ductal epithelium of the guinea pig pancreas and that 5-HT strongly inhibits secretinand ACh-stimulated fluid secretion as well as basal secretion in interlobular duct segments via the basolateral $5-\mathrm{HT}_{3}$ receptor on duct cells. The inhibition is probably due to the reduced uptake of $\mathrm{HCO}_{3}{ }^{-}$via $\mathrm{Na}^{+}-$ $\mathrm{HCO}_{3}{ }^{-}$cotransport across the basolateral membrane. A small elevation of the intraductal pressure in vivo reduced secretin-stimulated fluid secretion, which was attenuated by granisetron, a $5-\mathrm{HT}_{3}$ receptor antagonist. Thus the ductal EC cells may function as intraductal pressure sensors and regulate fluid secretion of neighboring duct cells in a paracrine fashion.

\section{Acknowledgments}

This study was supported by grants from Japan Society for the Promotion of Science and Uehara Memorial Foundation. We thank S. Kobayashi, M. C. Steward, V. Wray, and Y. Sohma for helpful discussions.

1. Sjolund, K., Sanden, G., Hakanson, R., and Sundler, F. 1983. Endocrine cells in human intestine: an immunocytochemical study. Gastroenterology. 85:1120-1130.

2. Gershon, M.D., Kirchgessner, A.L., and Wade, P.R. 1994. Functional anatomy of the enteric nervous system. In Physiology of the gastrointestinal tract. L.R. Johnson, editor. Raven Press. New York, New York, USA. 381-422.

3. Nilsson, O., Ahlman, H., Geffard, M., Dahlström, A., and Ericson, L.E. 1987. Bipolarity of duodenal enterochromaffin cells in the rat. Cell Tissue Res. 248:49-54.

4. Bülbring, E., and Crema, A. 1959. The release of 5-hydroxytryptamine in relation to pressure exerted on the intestinal mucosa. J. Physiol. 146:18-28.

5. Hubel, K.A., Renquist, K.S., and Varley, G. 1991. Secretory reflexes in 
ileum and jejunum: absence of remote effects. J. Auton. Nerv. Syst. 35:53-62.

6. Gale, J.D., and Bunce, K.T. 1996. Pharmacological characterization of 5 -hydroxytryptamine receptors in the gastrointestinal tract. In Serotonin and gastrointestinal function. T.S. Gaginella and J.J. Galligan, editors. CRC Press. Boca Raton, Florida, USA. 33-52.

7. Ekholm, R., Ericson, L.E., and Lundquist, I. 1971. Monoamines in the pancreatic islets of the mouse: subcellular localization of 5-hydroxytryptamine by electron microscopic autoradiography. Diabetologia. 7:339-348.

8. Cetin, Y. 1992. Biogenic amines in the guinea pig endocrine pancreas Life Sci. 50:1343-1350.

9. Kirchgessner, A.L., and Gershon, M.D. 1990. Innervation of the pancreas by neurons in the gut. J. Neurosci. 10:1626-1642.

10. Ishiguro, H., et al. 1998. Fluid secretion in interlobular ducts isolated from guinea-pig pancreas. J. Physiol. 511:407-422.

11. Ieda, H., et al. 1998. Coexistence of proguanylin (1-15) and somatostatin in the gastrointestinal tract. J. Gastroenterol. Hepatol. 13:1255-1233.

12. Ishiguro, H., Steward, M.C., Lindsay, A.R.G., and Case, R.M. 1996. Accumulation of intracellular $\mathrm{HCO}_{3}{ }^{-}$by $\mathrm{Na}^{+}-\mathrm{HCO}_{3}{ }^{-}$cotransport in interlobular ducts from guinea-pig pancreas. J. Physiol. 495:169-178.

13. Steward, M.C., Lang, T.F., San-Román, J.I., and Case, R.M. 1998. Measurement of secretory rate in isolated pancreatic duct segments by digital videomicroscopy. J. Physiol. 509:3P. (Abstr.)

14. Ko, S.B.H., et al. 1999. Arginine vasopressin inhibits fluid secretion in guinea pig pancreatic duct cells. Am. J. Physiol. 277:G48-G54.

15. Gylfe, E. 1978. Association between 5-hydroxytryptamine release and insulin secretion. J. Endocrinol. 78:239-248.

16. Ohtani, O. 1983. Microcirculation of the pancreas: a correlative study of intravital microscopy with scanning electron microscopy of vascular corrosion casts. Arch. Histol. Jpn. 46:315-325.

17. Kirchgessner, A.L., and Gershon, M.D. 1995. Presynaptic inhibition by serotonin of nerve-mediated secretion of pancreatic amylase. Am. J. Phys iol. 268:G339-G345.

18. Masuda, M., Miyasaka, K., and Funakoshi, A. 1997. Involvement of 5hydroxytryptamine $(5-\mathrm{HT})_{3}$ receptor mechanisms in regulation of basal pancreatic secretion in conscious rats. J. Auton. Nerv. Syst. 62:58-62.

19. Li, Y., Hao, Y., Zhu, J., and Owyang, C. 2000. Serotonin released from intestinal enterochromaffin cells mediates luminal non-cholecystokinin-stimulated pancreatic secretion in rats. Gastroenterology. 118:1197-1207.

20. Case, R.M., and Argent, B.E. 1993. Pancreatic duct cell secretion: control and mechanisms of transport. In The pancreas: biology, pathobiology and disease. V.L.W. Go, et al, editors. Raven Press. New York, New York, USA. 301-350.
21. Cooke, H.J., Wang, Y.-Z., Frieling, T., and Wood, J.D. 1991. Neural 5hydroxytryptamine receptors regulate chloride secretion in guinea pig distal colon. Am. J. Physiol. 261:G833-G840.

22. Kuwahara, A., Kuramoto, H., and Kadowaki, M. 1998. 5-HT activates nitric oxide-generating neurons to stimulate chloride secretion in guinea pig distal colon. Am. J. Physiol. 275:G829-G834.

23. Garner, C., Feniuk, W., and Brown, P.D. 1993. Serotonin activates $\mathrm{Cl}$ channels in the apical membrane of rat choroid plexus epithelial cells. Eur. J. Pharmacol. 239:31-37.

24. Jung, J.S., Oh, S.O., Kim, M.G., Kang, D.S., and Lee, S.H. 1997. $\mathrm{Cl}^{-}$secretion induced by 5 -hydroxytryptamine and calcitonin gene-related peptide in rat tracheal epithelia. Pflügers Arch. 435:20-27.

25. Leung, G.P.H., Dun, S.L., Dun, N.J., and Wong, P.Y.D. 1999. Serotonin via $5-\mathrm{HT}_{1 \mathrm{~B}}$ and $5-\mathrm{HT}_{2 \mathrm{~B}}$ receptors stimulates anion secretion in the rat epididymal epithelium. J. Physiol. 519:657-667.

26. Ashton, N., Argent, B.E., and Green, R. 1990. Effect of vasoactive intestinal peptide, bombesin and substance $P$ on fluid secretion by isolated rat pancreatic duct. J. Physiol. 427:471-482.

27. Ishiguro, $\mathrm{H}$., et al. 1999. Luminal ATP stimulates fluid and $\mathrm{HCO}_{3}{ }^{-}$secretion in the guinea-pig pancreatic duct. J. Physiol. 519:551-558.

28. Derkach, V., Surprenant, A., and North, R.A. 1989. 5- $\mathrm{HT}_{3}$ receptors are membrane ion channels. Nature. 339:706-709.

29. Maricq, A.V., Peterson, A.S., Brake, A.J., Myers, R.M., and Julius, D. 1991. Primary structure and functional expression of the $5 \mathrm{HT}_{3}$ receptor, a serotonin-gated ion channel. Science. 254:432-437.

30. Hoyer, D., et al. 1994. VII. International union of pharmacology classification of receptors for 5-hydroxytryptamine (serotonin). Pharmac. Rev. 46:157-203.

31. Pinkus, L.M., Sarbin, N.S., Barefoot, D.S., and Gordon, J.C. 1989. Association of $[3 \mathrm{H}]$ zacopride with $5-\mathrm{HT}_{3}$ binding sites. Eur. J. Pharmacal. 168:355-362.

32. Sakurai-Yamashita, Y., Yamashita, K., Yoshimura, M., and Taniyama, K. 2000. Differential localization of 5-hydroxytryptamine 3 and 5-hydroxytryptamine ${ }_{4}$ receptors in the human rectum. Life Sci. 66:31-34.

33. Doucet, E., Hamon, M., and Emerit, M.B. 1998. Immunolabelling of the rat intestinal tract with antibodies specific to the long form of the 5hydroxytryptamine 3 receptor. Neuroscience. 87:691-707.

34. Ishiguro, H., Steward, M.C., Wilson, R.W., and Case, R.M. 1996. Bicarbonate secretion in interlobular ducts from guinea-pig pancreas. J. Physiol. 495:179-191.

35. Gray, M.A., and Argent, B.E. 1990. Non-selective cation channel on pancreatic duct cells. Biochim. Biophys. Acta. 1029:33-42.

36. Tsuji, S., Anglade, P., Ozaki, T., Sazi, T., and Yokoyama, S. 1992. Peristaltic movement evoked in intestinal tube devoid of mucosa and submucosa. Jpn. J. Physiol. 42:363-375. 